\title{
REGRESI GENERALIZED POISSON UNTUK MEMODELKAN JUMLAH PENDERITA GIZI BURUK PADA BALITA DI SURABAYA
}

\author{
Mahfudhotin ${ }^{1}$ \\ ${ }^{1}$ Prodi Perbankan Syariah, Fakultas Ekonomi dan Bisnis Islam, IAIN Kediri \\ e-mail: mahfudhotin@iainkediri.ac.id
}

\begin{abstract}
Abstrak
Model regresi Generalized Poisson (GP) merupakan perluasan dari model regresi Poisson yang digunakan untuk mengatasi data yang mengalami underdispersi atau overdispersi. . Tujuan penelitian ini untuk mengestimasi parameter model linier tergeneralisasi dengan respon berdistribusi GP menggunakan maximum likelihood. Data yang digunakan dalam penerapan model regresi GP adalah data jumlah penderita balita gizi buruk di 25 kecamatan di Kota Surabaya tahun 2010 dengan variabel respon adalah jumlah penderita balita gizi buruk $(y)$, sedangkan variabel prediktor adalah jumlah penduduk nikah usia dini $\left(x_{1}\right)$, jumlah kepala keluarga tidak tamat SD $\left(x_{2}\right)$, jumlah bayi yang ikut posyandu $\left(x_{3}\right)$, jumlah tenaga medis $\left(x_{4}\right)$, jumlah kunjungan BKIA $\left(x_{5}\right)$, dan jumlah prosentase penduduk miskin $\left(x_{6}\right)$. Hasil model regresi GP dengan statistik diperoleh kesimpulan bahwa jumlah penderita balita gizi buruk dipengaruhi oleh jumlah kunjungan BKIA di tiap kecamatan kota Surabaya dan jumlah kepala keluarga tidak tamat SD menggambarkan tingkat pendidikan orang tua untuk terhadap pemberian asupan gizi yang seimbang.

Kata Kunci: The Marasmus Kwashiorkor, Distribusi Generalized Poisson I, Overdispersi.
\end{abstract}

\begin{abstract}
The expansion of Poisson regression model which is used to solve the underdispersion data or overdispersion data known as Generalized Poisson (GP) regression model. The purpose of this final project is getting the parameter estimator of generalized linear model with response for GP distribution using maximum likelihood. This GP regression model can be applied on the data of number of Marasmus Kwashiorkor patients in 25 subdistrict in Surabaya city in 2010. The variable response is the number of Marasmus Kwashiorkor patients $(\boldsymbol{y})$, where as the predictor responses are the number of people who married at early age $\left(\boldsymbol{x}_{\mathbf{1}}\right)$, the number of family heads who not graduated elementary school $\left(\boldsymbol{x}_{\mathbf{2}}\right)$, the number of children who participated posyandu $\left(\boldsymbol{x}_{\mathbf{3}}\right)$, the number of medical $\left(\boldsymbol{x}_{\mathbf{4}}\right)$, the number of visits BKIA $\left(\boldsymbol{x}_{\mathbf{5}}\right)$, and the number of poor population $\left(\boldsymbol{x}_{\mathbf{6}}\right)$. The result of the GP regression model with statistic test can be concluded that the number of Marasmus Kwashiorkor patients affected by the number of visits BKIA and education levels of parents.
\end{abstract}

Keywords: The Marasmus Kwashiorkor, Generalized Poisson I Distribution, Overdispersion. 


\section{PENDAHULUAN}

Gizi di bawah garis merah atau lebih dikenal dengan gizi buruk adalah keadaan kurang gizi tingkat berat yang disebabkan oleh rendahnya konsumsi protein dan energi dari makanan sehari-hari dan terjadi dalam waktu yang cukup lama. Gejala-gejala klinis dari gizi buruk secara garis besar dapat dibedakan menjadi marasmus, kwashiorkor atau marasmickwashiorkor (Anonim n.d.). Timbulnya penyakit gizi buruk telah menjadi masalah kesehatan yang serius pada banyak negara berkembang. Menurut Sensus WHO menunjukkan $49 \%$ dari 10,4 juta kematian yang terjadi pada anak dibawah lima tahun di negara berkembang. Kasuskasus kekurangan gizi tercatat sebanyak 50\% anak-anak di Asia, 30\% anak-anak Afrika, dan 20\% anak-anak di Amerika Latin (Arisman 2010)

Penyebaran penyakit gizi buruk di Indonesia cukup signifikan, bahkan seluruh wilayah Indonesia mempunyai proporsi yang cukup tinggi untuk terjangkit penyakit gizi buruk , khususnya di kota Surabaya. Padatnya penduduk di kota Surabaya dan adanya keterkaitan sebaran penderita gizi buruk antara satu kecamatan dengan kecamatan yang lainnya tidak merata. Selain itu, asupan gizi anak dan ibu dipengaruhi oleh faktor pendidikan dan perilaku serta keadaan kesehatan anggota rumah tangga. Sanitasi lingkungan dan pelayanan kesehatan adalah tersedianya air bersih dan sarana pelayanan kesehatan dasar yang terjangkau oleh seluruh keluarga. Hal ini menjadikan kota Surabaya merupakan salah satu daerah yang cenderung memiliki probalitas penyakit gizi buruk yang cukup besar. Seiring dengan meningkatnya kasus gizi buruk di Surabaya, pemerintah kabupaten Surabaya berusaha melakukan upaya agar penyakit gizi buruk tidak berkembang di kota tersebut dan juga harus diikuti tindakan-tindakan preventif oleh masyarakat (Arisman 2010).

Berdasarkan ilustrasi di atas, maka penyusun tertarik untuk membantu mengatasi masalah penyebaran penyakit gizi buruk di Surabaya dengan membuat pemodelan statistika. Pemodelan statistika merupakan suatu cara yang ditempuh untuk merumuskan sebuah masalah dalam suatu persamaan atau fungsi dengan menggunakan metode statistika. Model regresi yang sangat tepat digunakan dalam masalah ini adalah Generalized Poisson (GP). Penggunaan model regresi Poisson memungkinkan terjadinya underestimate pada standart error dan overstate sehingga mengacaukan tingkat signifikansi parameter regresinya, yang seharusnya sudah signifikan menjadi tidak signifikan atau sebaliknya. Faktanya, variabel respon yaitu jumlah penderita gizi buruk yang berdistribusi Poisson memungkinkan trejadi overdispersion yang berarti variansinya lebih besar dari pada mean (Ismail and Jemain 2005).

Fenomena penderita gizi buruk di setiap lokasi pos pengamatan memiliki keheterogenan yang cukup tinggi, dimana keheterogenan ini disebabkan oleh perbedaan letak lintang bujur dan ketinggian permukaan tanah yang berbeda-beda sehingga mengakibatkan karakteristik penderita gizi buruk pada lokasi pos pengamatan yang berdekatan dapat berbeda sehingga model bersifat overdispersion . Berdasarkan uraian tentang pemodelan penyebaran penyakit gizi buruk dengan Generalized Poisson dengan data overdispersion sehingga diharapkan masyarakat dapat lebih mudah memperoleh informasi mengenai gizi buruk dan faktor-faktor penyebabnya.

\section{METODE PENELITIAN}

Metode Penelitian yang digunakan pada penelitian ini adalah studi literatur dengan melihat teori teori yang terkait dengan GP. Sehingga diperoleh prosedur penelitian sebagai berikut : 
1. Pengumpulan data jumlah penderita gizi buruk di 25 kecamatan yang tersebar pada wilayah kota Surabaya yaitu Surabaya Selatan, Surabaya Barat, Surabaya Pusat, Surabaya Utara, dan Surabaya Timur. Lebih lanjut, memasukkan ke dalam model sesuai dengan langkah di atas.

2. Mendapatkan data jumlah balita penderita gizi buruk (variabel respons) dari Dinas Kesehatan (Dinkes) Surabaya dan variabel prediktor dalam metode Generalized Poisson, yaitu berupa data yang mempengaruhi jumlah balita penderita gizi buruk yang diperoleh dari Badan Pengembangan Masyarakat (Bapemmas), dan Badan Pusat Statistik (BPS) yang tersebar di wilayah surabaya.

3. Mendapatkan variabel-variabel prediktor dalam metode Generalized Poisson (berupa data yang mempengaruhi jumlah kejadian penderita gizi buruk pada data yang diperoleh dari Dinkes Surabaya dan Posyandu atau Puskesmas yang tersebar di wilayah surabaya)

4. Membuat model dengan pendekatan Generalized Poisson dengan tahap - tahap sebagai berikut :

a. Mengasumsikan $n$ data berpasangan $\left(y_{i} ; x_{0 i}, x_{1 i}, x_{2 i}, \cdots, x_{k i}\right), i=1,2, \ldots, n$

b. Mengasumsikan variabel random $y_{i}$ independent berdistribusi Generalized Poisson I dengan pdf

$\operatorname{Pr}\left(y_{i}, \mu_{i}, a\right)=\left(\frac{\mu_{i}}{1+a \mu_{i}}\right)^{y_{i}} \frac{\left(1+a y_{i}\right)^{\left(y_{i}-1\right)}}{y_{i} !} \exp \left(-\frac{\mu_{i}\left(1+a y_{i}\right)}{1+a \mu_{i}}\right), y_{i}=0,1,2, \ldots$

$\mu_{i}=\exp \left(\boldsymbol{X}_{i}^{T} \beta\right)$

dengan :

$y_{i}$ adalah nilai variable respon pada pengamatan ke- $i$,

$\boldsymbol{X}$ adalah matriks kovariat dari variable prediktor berukuran $(n x(p+1))$

$a$ adalah parameter disperse berbentuk scalar,

$\beta$ adalah parameter regresi berbentuk vector berukuran $((p+1) x 1)$

Mean diasumsikan sama dengan $E\left(Y_{i}\right)=\mu_{i}$ dan variansi sama dengan $\left(Y_{i}\right)=\mu_{i}\left(1+a \mu_{i}\right)^{2}$.

c. Menentukan fungsi likelihood dari langkah (b), yaitu :

$L=\prod_{i=1}^{n}\left(\frac{\mu_{i}}{1+a \mu_{i}}\right)^{y_{i}} \frac{\left(1+a y_{i}\right)^{\left(y_{i}-1\right)}}{y_{i} !} \exp \left(-\frac{\mu_{i}\left(1+a y_{i}\right)}{1+a \mu_{i}}\right)$ 
d. Menentukan fungsi log-likelihood dari langkah (c), yaitu :

$$
\ell=\sum_{i=1}^{n} y_{i} \ln \left(\frac{\mu_{i}}{1+a \mu_{i}}\right)+\left(y_{i}-1\right) \ln \left(1+a y_{i}\right)-\frac{\mu_{i}\left(1+a y_{i}\right)}{1+a \mu_{i}}-\ln \left(y_{i} !\right)
$$

dengan $\mu_{i}=\exp \left(\boldsymbol{X}_{i}^{T} \boldsymbol{\beta}\right)$.

e. Mengestimasi parameter $\boldsymbol{\beta}$ dan $a$ dengan langkah-langkah sebagai berikut:

$>$ Mendiferensialkan hasil log-likelihood dari langkah (d) terhadap parameter $\boldsymbol{a}$ dan $\boldsymbol{\beta}$.

$>$ Bentuk diferensiasi pada langkah (i) disamadengankan nol sebagai syarat perlu untuk memaksimumkan fungsi log-likelihood dan diselesaikan.

Melakukan pendekatan iterasi, khususnya dengan menggunakan algoritma NewtonRaphson karena pada langkah (c) diperoleh persamaan yang berbentuk implisit. Algoritma Newton-Raphson sebagai berikut :

- menentukan $m=0$, dan nilai awal estimator parameter $\boldsymbol{\theta}^{m}=\left(\boldsymbol{\beta}^{m}, a^{m}\right)$.

- menghitung $F\left(\widehat{\boldsymbol{\theta}}^{m}\right)$ dan $H\left(\widehat{\boldsymbol{\theta}}^{m}\right)$ dengan :

$$
\begin{aligned}
\boldsymbol{F}\left(\widehat{\boldsymbol{\theta}}^{m}\right)= & \left.\frac{\partial \ell}{\partial \beta_{0}}, \frac{\partial \ell}{\partial \beta_{1}}, \frac{\partial \ell}{\partial \beta_{2}}, \cdots, \frac{\partial \ell}{\partial \beta_{k}}, \frac{\partial \ell}{\partial a}\right)^{T} \\
H\left(\widehat{\boldsymbol{\theta}}^{m}\right)= & {\left[\begin{array}{ccccc}
\frac{\partial^{2} \ell}{\partial \beta_{0}^{2}} & \frac{\partial^{2} \ell}{\partial \beta_{0} \partial \beta_{1}} & \cdots & \frac{\partial^{2} \ell}{\partial \beta_{0} \partial \beta_{k}} & \frac{\partial^{2} \ell}{\partial \beta_{0} \partial a} \\
\frac{\partial^{2} \ell}{\partial \beta_{1} \partial \beta_{0}} & \frac{\partial^{2} \ell}{\partial \beta_{1}^{2}} & \cdots & \frac{\partial^{2} \ell}{\partial \beta_{1} \partial \beta_{k}} & \frac{\partial^{2} \ell}{\partial \beta_{1} \partial a} \\
\vdots & \vdots & \ddots & \vdots & \vdots \\
\frac{\partial^{2} \ell}{\partial \beta_{k} \partial \beta_{0}} & \frac{\partial^{2} \ell}{\partial \beta_{k} \partial \beta_{1}} & \cdots & \frac{\partial^{2} \ell}{\partial \beta_{k}{ }^{2}} & \frac{\partial^{2} \ell}{\partial \beta_{k} \partial a} \\
\frac{\partial^{2} \ell}{\partial a \partial \beta_{0}} & \frac{\partial^{2} \ell}{\partial a \partial \beta_{1}} & \cdots & \frac{\partial^{2} \ell}{\partial a \partial \beta_{k}} & \frac{\partial^{2} \ell}{\partial a^{2}}
\end{array}\right] }
\end{aligned}
$$

- hitung :

$$
\widehat{\boldsymbol{\theta}}^{m+1}=\widehat{\boldsymbol{\theta}}^{m}-H\left(\widehat{\boldsymbol{\theta}}^{m}\right)^{-1} F\left(\widehat{\boldsymbol{\theta}}^{m}\right)
$$

- Memaksimum $\left|\widehat{\boldsymbol{\theta}}^{m+1}-\widehat{\boldsymbol{\theta}}^{m}\right| \leq \varepsilon$, maka lanjutkan ke langkah 5, tetapi jika Maksimum $\left|\widehat{\boldsymbol{\theta}}^{m+1}-\widehat{\boldsymbol{\theta}}^{m}\right|>\varepsilon$, maka ulangi langkah 3 dengan mengganti $m=m+$ 1

- Mendapatkan estimator $\widehat{\boldsymbol{\theta}}$.

f. Mengimplementasikan program ke data yang mengalami overdispersion, yaitu $V\left(Y_{i}\right)>$ $E\left(Y_{i}\right)$, jika $a>0$ dengan variansi lebih besar dari mean, $E\left(Y_{i} \mid x_{i}\right)>V\left(Y_{i} \mid x_{i}\right)$ dan pada situasi ini model regresi menunjukkan data mengalami overdispersion. Jika $a>0$, maka variansi lebih kecil dari mean, $E\left(Y_{i} \mid x_{i}\right)<V\left(Y_{i} \mid x_{i}\right)$, menunjukkan data mengalami underdispersion. 
5. Memperoleh model jumlah penderita gizi buruk anak balita di Surabaya melalui dengan pendekatan Model Generalized Poisson

6. Mengetahui faktor - faktor apa saja yang paling berpengaruh pada kasus gizi buruk

7. Menyusun kesimpulan untuk menjawab permasalahan. Selain itu, diperlukan pula saran agar penelitian selanjutnya lebih baik.

Selanjutnya, Untuk lebih memahami mengenai penelitian ini akan diuraikan beberapa teori dasar yang digunakan pada penelitian ini.

\section{Distribusi Generalized Poisson}

$Y_{i}$ adalah variable random berdistribusi Generalized Poisson (GP), yang memiliki probability density function (pdf) (Ismail and Jemain 2005)

$f_{i}\left(y_{i} ; \mu_{i}, a\right)=\left(\frac{\mu_{i}}{\left(1+a \mu_{i}\right)}\right)^{y_{i}} \frac{\left(1+a y_{i}\right)^{y_{i}-1}}{y_{i} !} \exp \left(-\frac{\mu_{i}\left(1+a y_{i}\right)}{\left(1+a \mu_{i}\right)}\right), y_{i}=0,1,2, \ldots$

$\mu_{i}=\exp \left(\boldsymbol{X}_{i}^{T} \beta\right)$

dengan :

$y_{i}$ adalah nilai variable respon pada pengamatan ke- $i$,

$\boldsymbol{X}$ adalah matriks kovariat dari variable prediktor berukuran $(n x(p+1))$,

$a$ adalah parameter disperse berbentuk scalar,

$\beta$ adalah parameter regresi berbentuk vector berukuran $((p+1) x 1)$.

Mean diasumsikan sama dengan $E\left(Y_{i}\right)=\mu_{i}$ dan variansi sama dengan $\left(Y_{i}\right)=\mu_{i}\left(1+a \mu_{i}\right)^{2}$ (Hogg et al. 2013)

\section{Model Regresi Generalized Poisson}

Model regresi Generalized Poisson merupakan perluasan dari model regresi Poisson. Jika parameter dispersi $a$, sama dengan nol maka probability density function (pdf)

$$
f_{i}\left(y_{i} ; \mu_{i}, a\right)=\left(\frac{\mu_{i}}{\left(1+a \mu_{i}\right)}\right)^{y_{i}} \frac{\left(1+a y_{i}\right)^{y_{i}-1}}{y_{i} !} \exp \left(-\frac{\mu_{i}\left(1+a y_{i}\right)}{\left(1+a \mu_{i}\right)}\right), y_{i}=0,1,2, \ldots .
$$

Menjadi model regresi Poisson

$$
f\left(y_{i}\right)=\frac{\exp \left(-\mu_{i}\right) \mu_{i} y_{i}}{y_{i} !} \quad y_{i}=0,1,2, \ldots
$$

Dengan asumsi mean dan variansinya sama, yaitu $E\left(Y_{i} \mid x_{i}\right)=V\left(Y_{i} \mid x_{i}\right)$. Jika $a>0$, maka variansi lebih besar dari mean, $E\left(Y_{i} \mid x_{i}\right)>V\left(Y_{i} \mid x_{i}\right)$ dan pada situasi ini model regresi menunjukkan data mengalami overdispersion. Jika $a>0$, maka variansi lebih kecil dari mean, $E\left(Y_{i} \mid x_{i}\right)<V\left(Y_{i} \mid x_{i}\right)$, menunjukkan data mengalami underdispersion. Bentuk umum dari model regresi Generalized Poisson adalah 


$$
Y_{i}=\exp \left(X_{i}^{T} \beta\right) \quad i=1,2, \ldots \ldots, n
$$

dengan :

$i \quad$ adalah variabel respon berbentuk vector berukuran $(n \times 1)$,

$\boldsymbol{X}$ adalah matriks kovariat dari variabel prediktor berbentuk matriks berukukuran $(n x(n+$ 1))

$\beta$ adalah parameter regresi berbentuk vector berukuran $((p+1) x 1)$

Atau dapat juga ditulis sebagai berikut :

$$
\hat{Y}_{i}=\exp \left(\beta_{0}+\sum_{j=1}^{p} \beta_{j} x_{i j}\right)
$$

Dengan $i$ menyatakan unit eksperimen dan $j$ banyaknya variabel prediktor yang digunakan (Ismail and Jemain 2007)

\section{Estimasi Model Generalized Poisson dengan Metode Maximum Likelihood}

Hoog dan Craig (1995) mendeskripsikan sampel acak $Y_{1}, Y_{2}, \ldots, Y_{n}$ suatu distribusi dengan pdf $f(y, \beta)$, untuk $\beta \in \Omega$, dengan $\Omega$ ruang parameter. Pdf bersama antara $Y_{1}, Y_{2}, \ldots, Y_{n}$ untuk $f\left(y_{1} ; \beta\right), f\left(y_{1} ; \beta\right), \ldots, f\left(y_{n} ; \beta\right)$, apabila pdf tersebut dinyatakan fungsi terhadap $\beta$, ini dapat dikatakan sebagai fungsi likehood, dinotasikan L,

$$
\begin{aligned}
L\left(\beta ; y_{1}, y_{2}, \ldots, y_{n}\right) & =f\left(y_{1} ; \beta\right), f\left(y_{1} ; \beta\right), \ldots, f\left(y_{n} ; \beta\right) \\
& =\prod_{i=1}^{n} f\left(y_{i} ; \beta\right)
\end{aligned}
$$

dengan $\beta \in \Omega$

Jika statistik $\hat{\beta}=t\left(Y_{1}, Y_{2}, \ldots, Y\right)$ memaksimumkan $\left(\beta ; y_{1}, y_{2}, \ldots, y_{n}\right) ; \beta \epsilon \Omega$, dengan $\Omega$ ruang parameter, maka statistik $\hat{\beta}=t\left(Y_{1}, Y_{2}, \ldots, Y\right)$ dinamakan Maximum Likelihoodhood Estimator dari $\beta$ (Famoye et al. 2004)

\section{HASIL DAN PEMBAHASAN}

\subsection{Deteksi Awal Overdispersion pada $y_{i}$ dengan Menggunakan Software SPSS 17.0.}

Melakukan deteksi awal pada variable respon (Jumlah penderita gizi buruk di 25 kecamatan kota Surabaya) untuk mengetahui adanya Overdispersion dengan menggunakan Software SPSS 17.0. data mengalami Overdispersion apabila $V\left(Y_{i}\right)>E\left(Y_{i}\right)$. Dari hasil uji diperoleh p-value dengan nilai 0,000 pada tingkat signifikansi $\alpha=0,05$ sehingga variable respon tidak berdistribusi poisson dengan nilai mean sebesar 17,6129 dan variansi sebesar 284,845 . Hal ini berarti variable respon mengalami Overdispersion. 


\subsection{Pembentukan model Regresi Generalized Poisson dengan Variabel Prediktor yang Signifikan.}

Pada penjelasan rumus $E\left(Y_{i} \mid x_{i}\right)=\mu_{i}=\exp \left(\beta_{0}+\sum_{j=1}^{p} \beta_{j} x_{i j}\right)$, bentuk umum dari model regresi Generalized Poisson adalah :

$$
\hat{Y}_{i}=\exp \left(\beta_{0}+\sum_{i=1}^{4} \beta_{j} x_{i j}\right)
$$

Memperoleh estimasi model regresi Generalized Poisson di atas digunakan prosedur NLMIXED (nonlinier mixed) dalam Software SAS 9,0.

\subsection{Sumber Data}

Dalam penelitian ini, penulis secara langsung mengaplikasikan estimasi model Generalized Poisson dengan metode MLE pada data jumlah penderita balita gizi buruk yang diambil dari Dinas Kesehatan dan Badan Pusat Statistik (2010). Data sampel yang dijadikan objek penelitian merupakan jenis data cross sectional tentang jumlah penderita gizi buruk di kota Surabaya yaitu sebanyak 25 kecamatan yang meliputi semua wilayah Surabaya. Penelitian ini terdapat satu variabel respon yaitu : jumlah penduduk nikah usia dini $\left(x_{1}\right)$, jumlah kepala keluarga tidak tamat SD $\left(x_{2}\right)$, jumlah bayi yang ikut posyandu $\left(x_{3}\right)$, jumlah tenaga medis $\left(x_{4}\right)$, jumlah kunjungan BKIA $\left(x_{5}\right)$, dan jumlah prosentase penduduk miskin $\left(x_{6}\right)$. Dengan melakukan tahapan penelitian sebagai berikut :

a. Merumuskan dan mendefinisikan masalah

b. Menentukan studi kepustakaan

c. Membuat hipotesis

d. Mendefinisikan model atau desain penelitian

e. Menghimpun data

f. Menyajikan informasi

g. Menganalisis dan menginterprestasikan

h. Membuat generalisasi dan kesimpulan.

\subsection{Analisis Data}

Data yang digunakan adalah data jumlah penderita gizi buruk setiap kecamatan di Kota Surabaya sebanyak 25 kecamatan yang tersebar dari Surabaya Pusat, Surabaya Utara, Surabaya Timur, Surabaya Selatan, Surabaya Barat. Pemodelan dilakukan pada data jumlah penderita gizi buruk dengan pendekatan model regresi Generalized Poisson berdasarkan metode Maximum Likehood menggunakan bantuan software SAS.

\begin{tabular}{|l|c|c|c|l|}
\hline No & Estimator & $\begin{array}{l}\text { Standar } \\
\text { Error }\end{array}$ & $\mathrm{P}_{\text {value }}$ & Keputusan \\
\hline 1 & $\hat{\beta}_{0}$ & 0,5333 & 0,000 & Tolak $H_{0}$ \\
\hline 2 & $\hat{\beta}_{1}$ & 0,00514 & 0,563 & Terima $H_{0}$ \\
\hline 3 & $\hat{\beta}_{2}$ & 0,00029 & 0,035 & Tolak $H_{0}$ \\
\hline 4 & $\hat{\beta}_{3}$ & 0,00015 & 0,350 & Terima $H_{0}$ \\
\hline 5 & $\hat{\beta}_{4}$ & 0,01947 & 0,049 & Terima $H_{0}$ \\
\hline
\end{tabular}




\begin{tabular}{|l|c|c|c|l|}
\hline 6 & $\hat{\beta}_{5}$ & 0,00005 & 0,020 & Tolak $H_{0}$ \\
\hline 7 & $\hat{\beta}_{6}$ & 0,05516 & 0,214 & Terima $H_{0}$ \\
\hline 8 & $\hat{a}$ & 0,02579 & 0,001 & Tolak $H_{0}$ \\
\hline
\end{tabular}

Selanjutnya dilakukan pembentukan model Generalized Poisson dengan variabel prediktor yang signifikan diperoleh model

$$
\begin{gathered}
\hat{Y}_{i}=\exp \left(2,0268+0,003009 x_{i 1}+0,000667 x_{i 2}-0,00015 x_{i 3}+0,04012 x_{i 4}\right. \\
\left.-0,00014 x_{i 5}-0.07027 x_{i 6}\right)
\end{gathered}
$$

dan estimasi parameter dispersi yaitu $\hat{a}=0.1695$. Setelah dilakukan pengujian terhadap $a$ dapat disimpulkan bahwa variabel respon mengalami overdispersi.

\subsection{Pembahasan}

Pada kasus-kasus nyata jarang dijumpai data berdistribusi Poisson yang mempunyai mean dan variansi yang sama. Pelanggaran asumsi pada model regresi Poisson dengan mean dan variansi yang sama memungkinkan terjadinya underestimate pada standart error dan overstate. Sehingga terjadinya mean dan variansi yang tidak sama akan mengacaukan tingkat signifikansi parameter regresi pada data sampel yang bersifat overdispersion dan underestimate, yang seharusnya sudah signifikan menjadi tidak signifikan atau sebaliknya. Faktanya, variabel respon yaitu jumlah penderita gizi buruk yang berdistribusi Poisson memungkinkan terjadi overdispersion yang berarti variansinya lebih besar dari pada mean. Demikian juga untuk kasus penderita gizi buruk yang terjadi di wilayah kota Surabaya. Oleh karena itu dibutuhkan model alternatif untuk mengatasi data sampel yang bersifat overdispersion dan underestimate yaitu model regresi Generalized Poisson (Ismail and Jemain 2005)

Memperoleh estimasi model regresi Generalized Poisson di atas digunakan prosedur NLMIXED (nonlinier mixed) dalam Software SAS 9,0. Bentuk estimasi model regresi Generalized Poisson berdasarkan output prosedur NLMIXED dengan Software SAS 9,0 yaitu :

$$
\begin{gathered}
\hat{Y}_{i}=\exp \left(2,0268+0,003009 x_{i 1}+0,000667 x_{i 2}-0,00015 x_{i 3}+0,04012 x_{i 4}\right. \\
\left.-0,00014 x_{i 5}-0.07027 x_{i 6}\right)
\end{gathered}
$$

dan estimasi parameter dispersi yaitu $\hat{a}=0,08949$ dengan $i$ menyatakan banyaknya kecamatan yang ada di Kota Surabaya, sebanyak 25 kecamatan. Variable respon mengalami Overdispersion dilakukan pengujian terhadap $a$ dengan hipotesis sebagai berikut :

$$
\begin{aligned}
& H_{0}=a=0 \\
& H_{1}=a>0
\end{aligned}
$$

diperoleh $p$-value $=0,0019$ dengan tingkat signifikansi $\alpha=0,05$. Hal ini menunjukkan, $p$ value $<\alpha$ maka $H_{0}$ di Tolak sehingga dapat disimpulkan bahwa variabel respon mengalami Overdispersion. 
Berdasarkan tabel hasil estimasi parameter diperoleh Standart error terkecil yaitu untuk $\hat{\beta}_{2}$ dan $\hat{\beta}_{5}$. Selanjutnya dibandingkan antara $p$-value dengan $\alpha$ dari tabel NLMIXED, dan didapatkan nilai $p$-value $>0,05$ yaitu $\hat{\beta}_{1}, \hat{\beta}_{3}, \hat{\beta}_{4}$, dan $\hat{\beta}_{6}$ sehingga tidak memenuhi tingkat signifikansi model. Artinya semakin bertambahnya jumlah balita penderita gizi buruk di kota Surabaya tidak dipengaruhi oleh jumlah penduduk yang menikah pada usia dini, jumlah balita yang ikut posyandu, jumlah tenaga medis, dan jumlah prosentase penduduk miskin, akan tetapi faktor yang berpengaruh jumlah kepala keluarga tidak tamat SD dan jumlah kunjungan BKIA di tiap kecamatan kota Surabaya, sebesar :

$$
\begin{gathered}
\exp (0,000667)=1,000667222 \text { kali } \\
\exp (0,0667)=1,0687572 \text { kali }
\end{gathered}
$$

Jika jumlah kepala keluarga tidak tamat SD di tiap kecamatan kota Surabaya meningkat menjadi 100 kali dari semula, maka hal ini akan meningkatkan jumlah penderita balita gizi buruk sebesar 1,0680446 kali dari semula.

$$
\begin{gathered}
\exp (-0,00014)=0,999860009 \\
\exp (-0,014)=0,9892120009
\end{gathered}
$$

Jika jumlah kunjungan BKIA di tiap kecamatan kota Surabaya meningkat menjadi 100 kali dari semula, maka hal ini akan menurunkan jumlah penderita balita gizi buruk sebesar 0,9893505 kali dari semula. Jadi semakin bertambahnya jumlah balita penderita gizi buruk di Kota Surabaya dipengaruhi oleh jumlah kepala keluarga tidak tamat SD dan jumlah kunjungan BKIA di tiap kecamatan kota Surabaya.

\section{KESIMPULAN}

Dari hasil penerapan model Generalized Poisson pada data jumlah balita penderita gizi buruk di 25 kecamatan di kota Surabaya, diperoleh bahwa semakin bertambahnya jumlah balita penderita gizi buruk yang signifikan berpengaruh adalah jumlah kepala keluarga yang tidak tamat SD sebesar 1,0680446 kali meningkatkan jumlah penderita gizi buruk dan jumlah kunjungan BKIA sebesar $\exp (-0,014)=0,9892120009$ menurunkan jumlah penderita gizi buruk di tiap kecamatan kota Surabaya sebesar 100 kali dari semula. Hasil model regresi GP I dengan statistik diperoleh kesimpulan bahwa jumlah penderita balita gizi buruk dipengaruhi oleh jumlah kunjungan BKIA di tiap kecamatan kota Surabaya dan jumlah kepala keluarga tidak tamat SD menggambarkan tingkat pendidikan orang tua untuk terhadap pemberian asupan gizi yang seimbang.

\section{DAFTAR PUSTAKA}

Anonim, A. (n.d.). "Kwashiorkor dan Marasmus, Malanutrisi yang Mengancam Nyawa Alodokter," Available athttps://www.alodokter.com/kwashiorkor-dan-marasmusmalnutrisi-yang-mengancam-nyawa.

Arisman, A. (2010), Gizi Dalam Daur Kehidupan Buku Ajar Ilmu Gizi, Jakarta: EGC. Famoye, F., Wulu, J. T., and Singh, K. P. (2004), "On the Generalized Poisson Regression Model with an Application to Accident Data," Journal of Data Science, 2, 287295. 
Hogg, R. V., McKean, J. W., and Craig, A. T. (2013), Introduction to mathematical statistics, Boston: Pearson.

Ismail, N., and Jemain, A. A. (2005), "Generalized Poisson Regression: An Alternative for Risk Classification,” Jurnal Teknologi, 43, 39-54. https://doi.org/10.11113/jt.v43.770.

Ismail, N., and Jemain, A. A. (2007), "Handling Overdispersion with Negative Binomial and Generalized Poisson Regression Models.," Citeseer. 